\title{
Kovács Mihály
}

\section{A koronavírus-járványhelyzet során kialakított fogvatartási stratégiák bemutatása, a védekezéssel és megelőzéssel kapcsolatosan végrehajtott feladatok és jó gyakorlatok tükrében}

\author{
Presentation of detention strategies \\ for the coronavirus pandemic in the light of tasks and good \\ practices related to protection and prevention
}

\begin{abstract}
Absztrakt
A Magyarországot 2020 márciusában elérő COVID-19-járvány jelentősen befolyásolta az emberi kapcsolatok kommunikációs formáit, ez kiváltképp igaznak bizonyult a büntetés-végrehajtási szervezetre, így közvetlenül a fogvatartottakra is. Magyarország Kormánya, illetve a Nemzeti Népegészségügyi Központ iránymutatásainak megfelelően a büntetés-végrehajtási intézetekben fokozatosan kerültek bevezetésre a preventív intézkedések, amelyek a személyi állomány szolgálatellátására és a fogvatartottakra egyaránt hatással voltak. A bevezetett intézkedések - amelyek ideiglenesen a személyes látogatófogadás lehetőségét is korlátozták ellensúlyozására a telekommunikációs eszközök igénybevételével végrehajtott, ellenőrzött videóhívások rendszere rövid idő alatt magas szintü fejlesztésen esett át, és kiterjesztésre került a teljes fogvatartotti állomány részére. A tanulmány célja, hogy bemutassa a járvánnyal érintett időszak kapcsolattartási formáinak megváltozását, a személyes kapcsolattartások mennyiségi és minőségi gyakorlásának más platformokra történő áthelyeződését. A prezentáció elkészítése során a Skype, a fogvatartotti mobiltelefonok, és a pandémiás időszakot megelőző látogatófogadások statisztikai adatai kerültek felhasználásra. Ezen felül a járványhelyzettel kapcsolatos fogvatartási stratégiák, a védekezés és megelőzés céljából végrehajtott feladatok és jó gyakorlatok kerülnek bemutatásra. Az előadás eredményeként megállapítható, hogy a büntetés-végrehajtási szervezet a fogvatartotti jogokat - kiemelten a kapcsolattartásra vonatkozókat - a járványhelyzet alatt is folyamatosan biztosította, a jó gyakorlatok beépítésre kerültek az alapmüködésébe.
\end{abstract}


Kulcsszavak: COVID-19, pandémia, fogvatartási stratégia, jó gyakorlatok

\begin{abstract}
The COVID-19 epidemic, that reached Hungary in March, 2020, significantly affected the forms of communication in human relations. This proved to be especially true for the Hungarian Prison Service, and also directly for the prisoners. In accordance with the guidelines of the Hungarian Government and the National Public Health Centre, preventive measures were introduced in prisons gradually, this had an impact both on the duty service of the personnel and on the detainees. The introduced measures limited the possibility of receiving personal visitors temporarily, and as a compensation the system of controlled video calls using telecommunication tools was quickly developed and extended to the entire prison population. The aim of the presentation is to show the change in the forms of contact during the pandemic period, the transfer of the quantitative and qualitative practice of personal contacts to other platforms. For the preparation of the presentation, statistical data of Skype calls, approved detainee mobile phones, and also of visitor receptions before the pandemic period were used. In addition, detention strategies in connection with the pandemic situation, tasks performed for control and prevention, and good practices will be presented. As a result of the presentation, it can be stated that the Hungarian Prison Service continuously ensured the rights of prisoners, especially rights related to contact, even during the pandemic, and good practices were incorporated into the basic operation.
\end{abstract}

Keywords: COVID-19, pandemic, detention strategy, good practices

\title{
Bevezetés
}

A SARS-CoV-2 koronavírus terjedése kapcsán elmondható, hogy a 2020 márciusában Magyarországot is elérő világjárvány eddig ismeretlen, rendkívüli helyzet elé állította a hazánkban élö embereket, és a pandémiás helyzet természetesen hatással volt a büntetés-végrehajtási szervezet (továbbiakban: bv. szervezet) szakmai tevékenységére is. Néhány hét leforgása alatt olyan döntéseket kellett meghozni, majd azokat végrehajtani, amelyekben mindaddig nem volt sem elméleti, sem gyakorlati tapasztalata a bv. szervezetnek. A Büntetés-végrehajtás Országos Parancsnoksága (továbbiakban: BVOP) - figyelemmel a Magyarország Kormánya által bevezetett intézkedésekre, valamint a Nemzeti Népegészségügyi Központ iránymutatásaira - fokozatosan vezetett be preventív jellegü, illetve korlátozó intézkedéseket a 2020. március 5-én megalakult Operatív Törzs 
útján. Minden lépés és döntés igazodott a járvány terjedéséhez és sajátosságaihoz, de az emberélet megóvása mellett minden esetben törekedtek a biztonságos fogvatartásra, és arra, hogy a fogvatartottak jogai csak a lehető legkisebb mértékben sérüljenek. A bv. szervezet kiemelten kezelte mindazokat a kockázatcsökkentő intézkedéseket, amelyek közvetlenül a büntetés-végrehajtási intézetek (a továbbiakban: bv. intézet) személyi állományának, közvetve pedig a hozzátartozók, és nem utolsósorban a fogvatartottak egészségének megőrzését szolgálták. Ezen csoportok megfertőződésének megelőzése és a vírus bv. intézetekbe történő bejutásának megakadályozása magas prioritást élvezett.

Az elrendelt veszélyhelyzet és annak hozadékai a kezdetektől negatív hatással voltak a fogvatartottak hangulatára is, amelynek hatékony kezelésére - a járványkezelés mellett - rövid időn belül szükség volt. Az intézkedések meghozatalánál természetesen mind a mai napig fő szempont a járvány bv. intézetekbe történő bejutásának, majd elterjedésének megakadályozása, azonban nem lehetett figyelmen kívül hagyni a korlátozó intézkedések, valamint a hozzátartozók irányába érzett aggodalom fogvatartotti hangulatra gyakorolt negatív hatását sem. Előbbiek okán a dinamikus biztonság egyik alapelemének számító fogvatartotti hangulat kezelése mindvégig kiemelt jelentőségü volt.

Ahogy a járvány terjedésének üteméről és a vírus természetéről egyre több információ birtokába került az ország, a büntetés-végrehajtás országos parancsnoka, valamint a döntésre jogosult szakterületi vezetők - azok figyelembevételével - folyamatosan finomították a mindennapi szolgálatellátás támogatása és hatékonyságának növelése szempontjából szükségesnek ítélt intézkedéseket. Így eddig hét, a teljes bv. szervezetet érintő intézkedési terv és azok módosításai, valamint szakterületenként számos feladatszabó levél, végrehajtást segítő módszertani útmutató és protokoll, illetve a fogvatartottaknak és a kapcsolattartóiknak szóló tájékoztató anyag született preventív jelleggel.

A tanulmány a reintegrációval összefüggő területek közül kiemelten a kapcsolattartásra fókuszál, hiszen ezt érintette legmélyebben a járványhelyzet. A vonatkozó törvényi szabályozás ${ }^{1}$ a látogatófogadáson kívül alapesetben - bizonyos feltételek fennállása mellett - hatféle módon teszi lehetővé a személyes érintkezést a fogvatartott és regisztrált kapcsolattartója között, melyek akár együtt járhatnak a bv. intézet elhagyásával is. A járványhelyzet tükrében hozott védelmi intézkedések épp ezeket szüntették meg, így - többek között - ennek áthidalására szükséges volt megoldást találni. A BVOP a fogvatartottak reintegrációja kapcsán illetékes szakterülete, a Fogvatartási Ügyek Szolgálata a társ

1 2013. évi CCXL. törvény a büntetések, az intézkedések és egyes kényszerintézkedések és a szabálysértési elzárás végrehajtásáról, 116. § (1) bek., 123. § (1) bek., 173. § (1) bek. 
szakterületekkel való folyamatos együttmüködés mellett a pandémiás időszak teljes tartama alatt kiemelten kezelte a mindenkori aktuális védelmi intézkedések érvényesülését, ugyanakkor kiemelt figyelmet fordított a fogvatartottak kapcsolattartásának biztosítására, hangulatuk folyamatos monitorozására is.

\section{A reintegrációs szakterületet érintő fóbb intézkedések}

A COVID-19 magyarországi megjelenésétől kezdve a bv. szervezet nagy hangsúlyt fektetett a fogvatartottak és a kapcsolattartók tájékoztatására, melyhez igénybe vette a korszerü technikai lehetőségeket is. Tájékoztató plakátok készültek, a fogvatartottak közremüködésével rögzített videókat sugároztak a börtönökben elérhető zárt videóhálózaton, és az országos központi honlap mellett valamennyi bv. intézet a saját weboldalán folyamatosan tájékoztatta a külvilágot is, felhívva a figyelmet a megelőzés fontosságára, és ismertette az érintettekkel a meghozott védelmi intézkedéseket. A BVOP honlapján „,Megelözö intézkedések a koronavírus-járvány miatt a hazai börtönökben" (URL1) címmel a járványügyi helyzet alakulásáról - a fogvatartottak és hozzátartozóik tájékoztatására - külön menüpontot hozott létre a Kommunikációs Főosztály, amelyben valamennyi releváns közlemény megtalálható. A bv. szervezet úgynevezett „,call center” rendszert alakított ki a bv. intézetekben, amely naponta 07.00-15.00 óra közötti időintervallumban volt elérhető abból a célból, hogy az aktuális járványügyi helyzet miatt bevezetett intézkedésekről a telefonon érdeklődők számára hiteles információkat közöljön az arra kijelölt személyi állományi tagok útján (URL2).

A legelső intézkedések között volt egyes - már engedélyezett - ideiglenes intézetelhagyási formák végrehajtásának felfüggesztése. Ez azt jelentette, hogy azok a fogvatartottak, akiknek korábban kimaradást, eltávozást vagy látogató intézeten kívüli fogadását engedélyeztek - az intézkedést követő időszakra, akár jutalomból is -, azok nem élhettek ezzel a lehetőséggel. Ekkor a látogatófogadások a koronavírus bv. intézetbe történő bekerülésének megelőzése érdekében a fogvatartottak és a hozzátartozóik közötti fizikai érintkezés és testi kontaktus lehetőségét kizáró módon kerültek megszervezésre és végrehajtásra. Az ezt követően hozott rendelkezések - a magyarországi helyzet értékelése okán - már fontosnak tartották többek között a területileg illetékes igazságügyi és társ szervekkel történő kapcsolatfelvételt a videókonferencia végponton keresztül történő távtárgyalások és távmeghallgatások megvalósítása érdekében, az újonnan befogadott fogvatartottak 14 napos elkülönítését, és az átmenetileg beszüntethető munkahelyek és a digitális oktatás lehetőségének felmérését. Ezen túl - ami a fogvatartottak kapcsolattartását illeti - döntés született 
a rezsimkategóriától függően különböző tartamban meghatározott telefonálási időkeret egységesen 15 perccel történő megnöveléséről, a fogvatartotti mobiltelefonnal nem rendelkező fogvatartottak részére havi három alkalommal öt perc ingyenes telefonálás lehetőségének biztosításáról, valamint a kapcsolattartók számára lehetőség nyílt arra, hogy havi két darab csomagot rendeljenek a rendszeresített webshopfelületen.

A koronavírus-járvány elleni védekezést meghatározó intézkedés a kijárási korlátozás ${ }^{2}$ fényében meghozott azon döntés volt, mely szerint 2020. március 27 -étől kezdődően visszavonásig látogatási engedélyeket kiadni nem lehetett. Mindez alapjaiban változtatta meg a fogvatartottak kapcsolattartásának megszokott rendjét, és a személyi állomány részéről is más hozzáállást kívánt, hiszen a látogatás ideiglenes beszüntetésének fogvatartottakra gyakorolt negatív hatásait enyhítendő céllal és a kapcsolatok megóvásának szem előtt tartásával egyúttal széles körben bevezetésre került a Skype-alkalmazáson keresztül megvalósítható kapcsolattartás.

Ezt követően az aktualizált szabályozók már tartalmazták a fogvatartottakkal közvetlen kapcsolatba kerülö személyi állományi tagok maszkviselési kötelezettségét, a súlyos beteg hozzátartozó meglátogatásának és a temetésen való részvételnek a tiltását, a kizárólagos digitális oktatást, a fogvatartottak zárkán kívüli szájmaszkviselési kötelezettségét, valamint a 65 év feletti, illetve egészségi és mentális állapotuk miatt veszélyeztetett fogvatartottak többi fogvatartottól történő elkülönített, együttes elhelyezésének javaslatát.

Hosszabb idő elteltével kerültek megfogalmazásra az eddigieken túlmenő, további intézkedések, mint például a fogvatartottak zárkán kívül történő folyamatos maszkviselése, és a reintegrációs őrizet alkalmazási lehetőségének hivatalból történő vizsgálata a fogvatartotti populáció létszámának, ez által pedig a fertózés terjedésének csökkentése érdekében. A nyár folyamán a bv. intézetekben a távtárgyalások végpontjainak terheléscsökkentés, és a fogvatartottak bv. intézetekből, bírósági tárgyalásokra és rendőrségi meghallgatásokra történő előállítása következtében fellépő egészségügyi és biztonsági kockázat mérséklése érdekében tárgyalóhelyiségek kerültek kialakításra és használatbavételre.

A bevezetett intézkedések természetesen nem maradtak el a büntetés-végrehajtási pártfogó felügyelői (a továbbiakban: bv. pártfogó felügyelő) tevékenységet érintően sem. Fontos hangsúlyozni, hogy a bv. pártfogó felügyelö a fogvatartás időtartama alatt az elítéltek szabadulásra történő felkészítése során, valamint az egyes, ideiglenes intézetelhagyással járó jogintézmények elbírálását megalapozó döntésekhez a környezettanulmányok elkészítésekor, továbbá az elítélt szabadulását követően a büntetés-végrehajtási bíró által elrendelt pártfogó felügyelet

2 71/2020. (III. 27.) Korm. rendelet a kijárási korlátozásról. 
végrehajtása esetében vagy az önkéntesen igénybe vehető utógondozás ellátása és a kontrollfunkció érvényesítése érdekében, személyes kapcsolatfelvétel útján intézkedik az egyes ügyekben. A bv. pártfogó felügyelői vélemények és a környezettanulmányok elkészítésének fontos gyakorlati eleme, hogy a bv. pártfogó felügyelő az elítélt által megjelölt helyszínen, az elítélt által megnevezett kapcsolattartókkal személyes kontaktust teremt. Fentiekböl adódóan olyan szakemberről beszélünk, aki az ügyintézés során folyamatosan ,ingázik” a bv. intézet és az elítélt vagy pártfogolt, és hozzátartozói között. A koronavírus gyors terjedésének, valamint a megbetegedési esetszámok növekedésének figyelembevételével magas kockázatot jelentett az ügyintéző számára a különböző környezetben végzett tevékenységek végrehajtása. Ezen túl a reintegrációs őrizet jogintézményének engedélyezésére irányuló eljárásnak is része a megelőző szakértői vélemény elkészítése és a megjelölt ingatlan alkalmasságának felmérése, majd engedélyezés esetén a bv. pártfogó felügyelő ellenőrzést végez a megjelölt ingatlanokban. A veszélyhelyzet kihirdetésével összefüggésben egyes büntetés-végrehajtási szabályok módosításáról szóló 90/2020. (IV. 5.) Korm. rendeletben foglaltak e tekintetben a reintegrációs őrizet eljárásrendjét, a szakértői vélemények - pártfogói vélemények és környezettanulmányok - elkészítésének módját, továbbá a pártfogó felügyelet végrehajtásának egyes elemeit változtatták meg, amelyek fókuszpontjában az ügyfelekkel és az eljárásban érintett egyéb civil állampolgárokkal történő személyes kontaktus teljes mellózése áll, áttérve ezzel az elektronikus kapcsolattartásra. A környezettanulmányokat és a pártfogó felügyelöi véleményeket - beleértve a reintegrációs őrizet engedélyezésére kiadott elítélti kérelmek esetében az elektronikus távfelügyeleti eszköz alkalmazhatóságának felmérését is - kizárólag telefonos ügyintézés, valamint elektronikus kapcsolattartás útján lehetett elkészíteni. A bv. pártfogó felügyelők az elbíráláshoz szükséges, korábban személyesen beszerzett dokumentumokat e-mail útján kapták meg, az elítélt által megjelölt ingatlanról pedig fotókat kértek be. Az érintett hozzátartozókkal a személyes kommunikációt a telefon útján történő információbekérés váltotta fel. A pártfogó felügyeletet és az utógondozást - beleértve a kontrollfunkció érvényesítését is - az előbbiekhez hasonlóan, a személyes kontaktus teljes mellőzésével lehetett végrehajtani. A bv. pártfogó felügyeló által kiépített kapcsolatrendszerben érintett szervvel, szervezettel vagy intézménnyel szintén az elektronikus ügyintézés vált általánossá.

\section{A kapcsolattartási szabályok változásai és azok eredményessége}

A fogvatartottak és a hozzátartozóik közötti kapcsolat megléte egyrészt a szabadulást követő társadalmi reintegráció eredményességének szempontjából 
meghatározó, főként a bünismétlési és visszaesési kockázatok mentén kiemelten kezelt tényező, másrészt - különösen jelen helyzetben - komoly hatással van a fogvatartottak hangulatára. A befogadó környezet megléte vagy annak hiánya jelentős mértékben befolyásolja a fogvatartott szabadulását követő magatartását, beilleszkedési hajlandóságát. A koronavírus-járvánnyal összefüggésben kialakult, a bv. szervezetet is kiemelten érintő rendkívüli helyzet miatt bevezetett intézkedések hatására nagymértékben átalakult a fogvatartottak kapcsolattartási szokása. Ez a helyzet - bár ideiglenes jellegü okok miatt alakult ki - új alapokra helyezte a hozzátartozókkal való kommunikációt, különös tekintettel az audiovizuális kapcsolattartási formákra.

A progresszív rezsimszabályok meghatározzák, hogy az egyes végrehajtási fokozatokon belül a különböző rezsimkategóriákba tartozó fogvatartottak milyen rendszerességgel vehetnek igénybe bizonyos kapcsolattartási formákat. Ezt a metódust - a levelezés kivételével - ideiglenesen, de jelentősen átszabni kényszerült a bv. szervezet annak érdekében, hogy a koronavírus ne vagy csak minél kisebb mértékben jusson be a bv. intézetekbe, megóvva ezzel a fogvatartottak és a személyi állomány egészségét is. További szempont volt a látogatófogadás és az ideiglenes intézetelhagyási formák átmeneti szünetelésével a fogvatartottak körében szükségképpen elöidézett negatív hatások enyhítése. Az intézkedések alapja a veszélyhelyzet kihirdetésével összefüggésben az egyes büntetés-végrehajtási szabályok módosításáról szóló 90/2020. (IV. 5.) Korm. rendelet volt, mely döntéseket hozott a fogvatartottak eddigi kapcsolattartásának módjával összefüggésben az alábbiak szerint:

- „a járványügyi intézkedésre vagy az egészségügyi válsághelyzettel összefüggö más okra figyelemmel a büntetés-végrehajtás országos parancsnoka egy vagy több bv. intézet tekintetében korlátozhatja többek között az intézet elhagyásával járó kapcsolattartási formákat, valamint a látogató fogadást;

- a járványügyi intézkedéssel vagy az egészségügyi válsághelyzettel összefüggö korlátozások hátrányos következményeinek enyhitése érdekében az elitélt rezsimbe tartozásától függetlenül igénybe veheti a bv. intézet által nyújtott elektronikus kapcsolattartási formákat;

- a szabadságvesztés végrehajtási fokozataira és rezsimjeire vonatkozó rendelkezések szerinti gyakoriságot és idötartamot meghaladó mértékben kezdeményezhet telefonhivást, ha pedig ehhez szükséges letéti pénzzel nem rendelkezik, kérelmére, egyedi intézkedés alapján a bv. intézet a telefonálás dijjának költségeit átvállalhatja;

- havonta több alkalommal is fogadhat és küldhet csomagot." 
Az új intézkedések kedvezményeket nyújtottak a fogvatartottak részére a telefonálás és a csomagfogadás kibővítésével, illetve a Skype-alkalmazáson keresztül történő kapcsolattartás kiterjesztésével - mely utóbbi addig csak azon fogvatartottak számára volt elérhető, akiknek magatartása és egyéni teljesítménye kifogástalan, valamint biztonsági kockázati besorolása alacsony volt. E három kapcsolattartási forma népszerüsége veszélyhelyzeten kívül is eltérö, nem volt ez másképp a járványhelyzet idején sem. A 90/2020. (IV. 5.) Korm. rendelet 2020. június 18-ai hatályon kívül helyezését követően a veszélyhelyzet megszünésével összefüggő átmeneti szabályokról és a járványügyi készültségről szóló 2020. évi LVIII. törvény a fentieket változtatás nélkül határozta meg, így azok jelenleg is érvényben vannak.

\section{Telefonálás}

A járványhelyzet elején meghozott és a mai napig hatályos döntés szerint a végrehajtási fokozatonként és a rezsimkategóriánként különböző időtartamban meghatározott telefonálási időkeret egységesen 15 perccel megnövelésére került, továbbá a fogvatartotti mobiltelefonnal és letéti pénzzel nem rendelkezö fogvatartottak havonta háromszor öt percben a bv. intézet költéségére telefonálhattak.

1. számú ábra: A telefonhasználattal mobil vagy helyettesitö készülék által élö fogvatartottak plusz 15 perces kedvezményének felhasználási aránya (\%)

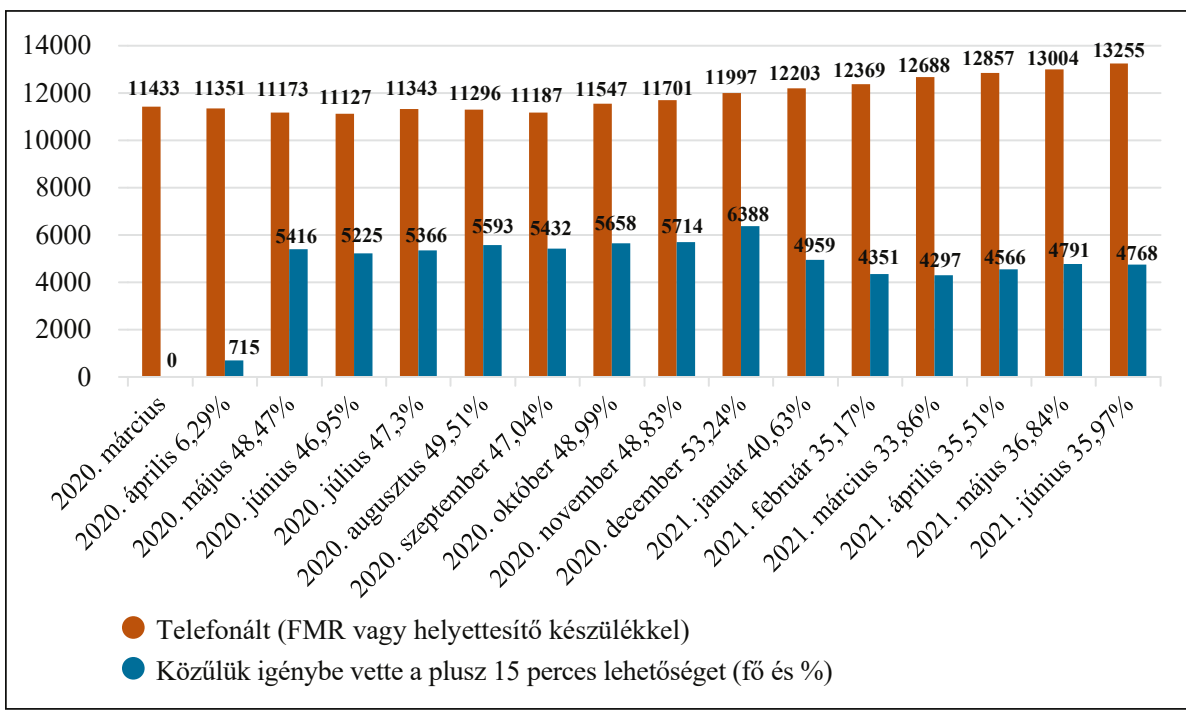

Forrás: Készítette a BVOP Fogvatartási Ügyek Szolgálata. 
Az FMR-készülékkel ${ }^{3}$ és/vagy felhasználható pénzzel ${ }^{4}$ rendelkező fogvatartottak száma hullámzó, de alapvetően növekvő tendenciát mutat. Közülük átlagosan 38,69\% használja ki a plusz 15 perces telefonhívás lehetőségét. Ez az arányszám viszonylag alacsonynak tekinthető, amiben szerepet játszik, hogy a fogvatartottak körében az ingyenesen igénybe vehető Skype-alapú kapcsolattartás népszerübbnek bizonyult.

2. számú ábra: A havi $3 \times 5$ perces hivásra jogosultak közötti kedvezmény felhasználása

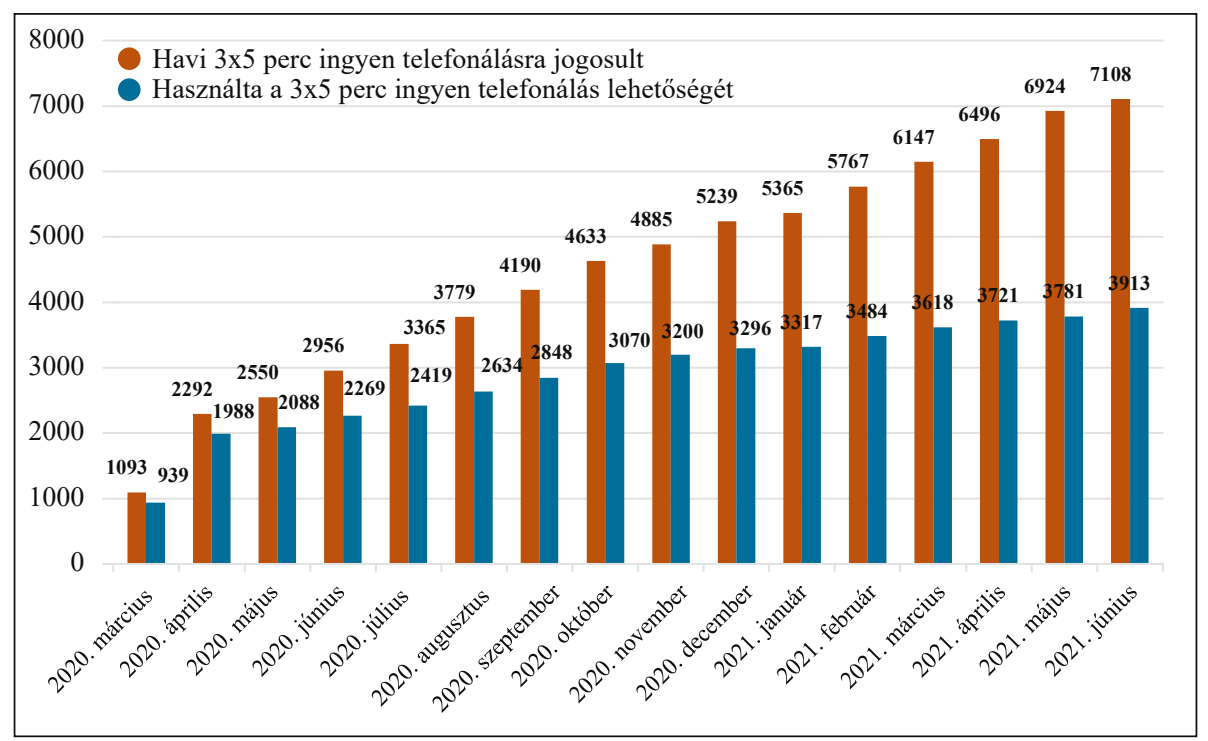

Forrás: Készítette a BVOP Fogvatartási Ügyek Szolgálata.

A telefonhasználatot illetően megállapítható, hogy az intézkedés hatályba lépését követően ${ }^{5}$ folyamatosan nőtt azon fogvatartottak száma, akik jogosultak a havi $3 \times 5$ perc ingyenes telefonálás lehetöségére, tehát nem rendelkeznek sem FMR-készülékkel, sem felhasználható pénzzel. Abban az esetben volt engedélyezhető az ingyenes hívás, amennyiben a fogvatartott nem dolgozott vagy nem kapott ösztöndíjat, vagy az adott hónapban nem volt letéti pénze. Ha elköltötte az aktuálisan rendelkezésre álló pénzét, fogvatartotti számláján aktuálisan

3 Célzottan a büntetés-végrehajtási szervezet részére kifejlesztett telekommunikációs eszköz, amely a fogvatartottak részére, bizonyos feltételek vállalása esetén, kapcsolattartás céljából kerül biztosításra.

4 A fogvatartott büntetés-végrehajtási számláján - hasonló a civil életben használat bankszámlához - szabadon felhasználható, nem lezárt (például szabadulásra elkülönített) összeg.

5 Hatálybalépés időpontja: 2020. 03. 15. 
nem állt rendelkezésre pénze, de indokolt volt a telefonálás, úgy a hívás egyedi elbírálás alapján engedélyezhető volt számára. Az ingyenes telefonálásban részesülők számának növekedése abból adódott, hogy a szabadulókhoz képest növekedés volt tapasztalható az új befogadottak - vagyis az ingyenes hívásra jogosulttá váló személyek - számában. Ennek következtében folyamatos növekedés volt megfigyelhető az átlaglétszám tekintetében, ezzel együtt pedig a nem dolgozó fogvatartottak számában is.

\section{Csomagfogadás}

Az átmeneti törvény ${ }^{6}$ felhatalmazása alapján az Intézkedési Terv 50. pontja meghatározta, hogy a járványügyi helyzetre tekintettel az elítéltek és egyéb jogcímen fogvatartottak kérelme esetén a kapcsolattartók részéről havonta két db, a bv. szervezet által kialakított webshopfelületen rendelt csomag, vagy egy db postai úton történő és egy db webshopfelületen rendelt csomag küldése engedélyezhető. Ennek ellenére ezzel a lehetőséggel a hozzátartozók kevéssé éltek, ugyanis a 2019. évi adatokhoz képest mind a webes felületen, mind a postai úton küldött általános csomagok száma csökkent. A webshopfelületen megrendelt csomagok száma 18\%-kal, a postán feladott csomagok száma 12\%-kal esett vissza 2020-ban az előző évhez képest. Ez visszavezethetö a járványhelyzet okozta esetleges munkahely elvesztéseket követően az érintett fogvatartottak családjainak anyagi helyzetére. Bár az interneten keresztül megrendelhető csomag ügyintézése korszerü és időtakarékos, mégis 2019-ben 34\%-kal, 2020-ban pedig 39\%-kal több csomag érkezett postán, mint webes rendelésen keresztül. Ennek oka a Skype-hoz hasonlóan az egyes kapcsolattartók korlátozott internet-hozzáférésében és informatikai tudásának hiányában keresendő. Feltehetőleg a kapcsolattartók még idegenkednek a webshopfelületen rendelt csomag feladásától, személyesebbnek élik meg az általuk megvásárolt termék beküldését, továbbá a webshopfelületen korlátozott az elérhető termékek típusainak választéka is - a folyamatosan bővülö termékkínálat ellenére -, amely a szerteágazó igényeket így kielégíteni még nem képes. A Bv. Holding Kft.-vel a kapcsolatot felvettük a jövőbeni, esetleges motivációs lehetőségek (mint például a második csomag kézbesítési költségének elengedése) kidolgozása érdekében.

6 A veszélyhelyzet megszünésével összefüggő átmeneti szabályokról és a járványügyi készültségről szóló 2020. évi LVIII. törvény. 
A személyes találkozással járó látogatófogadások megszüntetésével egyidejüleg a fogvatartottak kapcsolattartásának megóvása és erősítése céljából a videóhívás alkalmazása került előtérbe. A külvilággal való kapcsolat fenntartása a reintegráció, a társadalomba történő be-, illetve visszailleszkedés sikerének egyik alapköve, ezért a Skype kiterjesztéséről szóló rendelkezés kiadását követően valamennyi bv. intézetben és intézményben ${ }^{7}$ biztosításra kerültek a Skype-alkalmazáson keresztül végrehajtható videóhívások technikai feltételei, mely az esetlegesen szükséges helyiségek kialakításával és a számítástechnikai eszközök beszerzésével járt. A Skype-alkalmazás használatával megvalósuló kapcsolattartás elősegítése érdekében felhasználási útmutató készült az elítéltek hozzátartozói részére, amelyben részletesen ismertetésre kerültek a szükséges technika követelmények, és az online kommunikációs lehetőség használatának feltételei (URL3). A bv. intézetek jelenleg mindösszesen 285 db Skype-végponton keresztül bonyolítják le a fogvatartottak Skype-hívásait.

1. számú kép: Falra szerelt, videóhivásra alkalmas eszköz a Baranya Megyei Büntetés-végrehajtási Intézetben

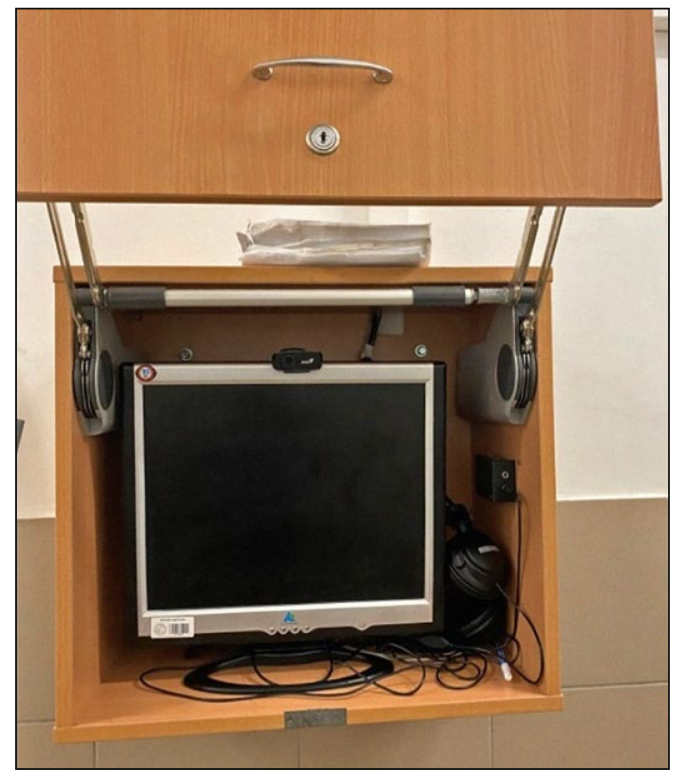

Forrás: A fotót készítette a BVOP Fogvatartási Ügyek Szolgálata.

7 Büntetés-végrehajtás Egészségügyi Központ és Igazságügyi Megfigyelő és Elmegyógyító Intézet. 
2. számú kép: Skype helyiség a Szombathelyi Országos Büntetés-végrehajtási Intézetben

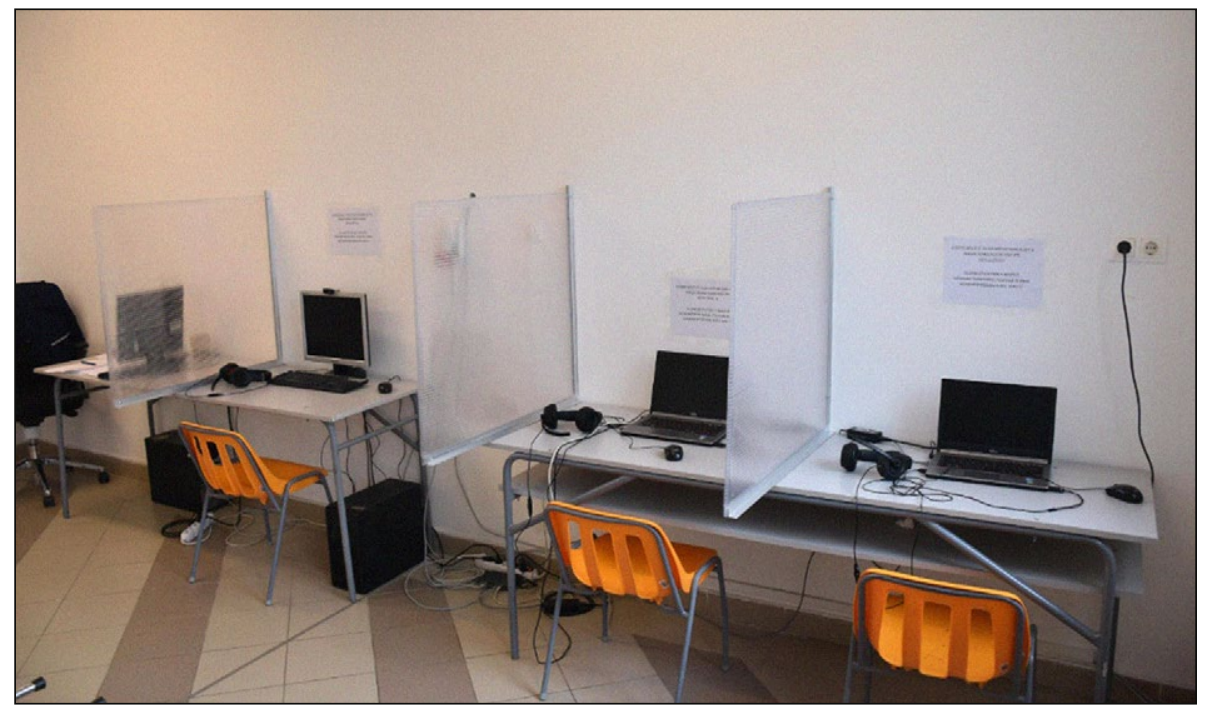

Forrás: A fotót készítette a BVOP Fogvatartási Ügyek Szolgálata.

3. számú kép: Skype-terem a Veszprém Megyei Büntetés-végrehajtási Intézetben

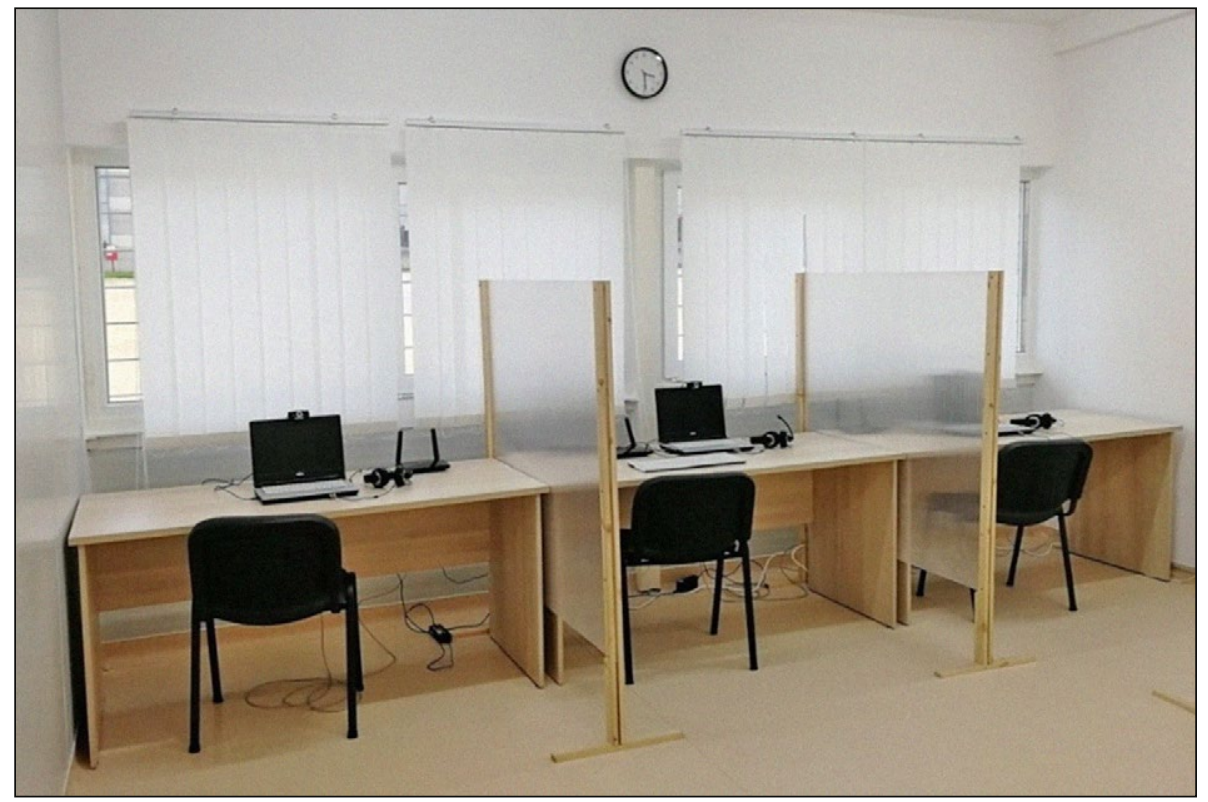

Forrás: A fotót készítette a BVOP Fogvatartási Ügyek Szolgálata.

76 Kovács Mihály: A koronavírus-járványhelyzet során kialakított fogvatartási stratégiák bemutatása, a védekezéssel és megelőzéssel kapcsolatosan végrehajtott feladatok és jó gyakorlatok tükrében 
A kapcsolattartók azonosítását - a látogatófogadáshoz hasonlóan - a személyazonosító igazolványok felmutatásával végezték el a személyi állomány tagjai, ami sok esetben nehézségbe ütközött az egyes kapcsolattartók nem megfelelő internetkapcsolata vagy eszközének alacsony képernyőfelbontása okán tapasztalt rossz képminőség miatt. Ennek megoldási lehetőségeként felmerült, hogy a fogvatartott és a kapcsolattartó között megkezdődö kommunikációt megelözően a személyi állomány tagja, amennyiben a kamerába történő felmutatás során a személyazonosító igazolványt nem megfelelő minőségben látja, úgy a videóhívás közben elérhető fájlcsatolással a kapcsolattartó a személyazonosító okmányának szkennelt/lefényképezett másolatát megküldi a személyazonosságának ellenőrzése céljából.

A Skype-hívások engedélyezhető időtartama a 2020. március 19-én kiadott szakmai protokoll, valamint annak módosítása alapján minimum 15 perc és maximum 60 perc között volt meghatározható az egyes alkalmak vonatkozásában. A büntetés-végrehajtás országos parancsnoka által, a koronavírus-járvánnyal összefüggő feladatok végrehajtására kiadott Intézkedési Terv I-VII is elöírta a Skype-hívások biztosításának kereteit, emellett a videóhívással megvalósuló elektronikus kapcsolattartás eljárásrendjéről szóló 37/2020. (VII. 24.) BVOP utasítás az addigi tapasztalatok figyelembevételével szabályozta a videóhívások engedélyezésének gyakorlatát.

Az intézkedés bevezetése óta a Skype-hívások száma kisebb hullámoktól eltekintve - melyeket az egyes ünnepi időszakokban tapasztalt magasabb felhasználási arány okozott - folyamatosan emelkedett. A legtöbb videóhívást lebonyolító - egyben a legnagyobb fogvatartotti létszámmal rendelkező - bv. intézetek havonta több mint $2000 \mathrm{db}$ videóhívást hajtanak végre, ami naponta több mint 65 megtörtént hívást jelent. A kiterjesztett müködés második és harmadik hónapjában (április és május), továbbá az év végén, az ünnepek közeledtével volt a legerőteljesebb a fejlődés. Márciusban 2361 db hívást indítottak az alkalmazáson keresztül, decemberben már 23 102, 2021. áprilisban pedig 27 217 db-ot, ami több mint tizenegyszeres növekedés. A müködés egy éve alatt eddig összesen 252893 db Skype-hívás valósult meg. 
3. számú ábra: Megtörtént Skype-hívások száma (db)

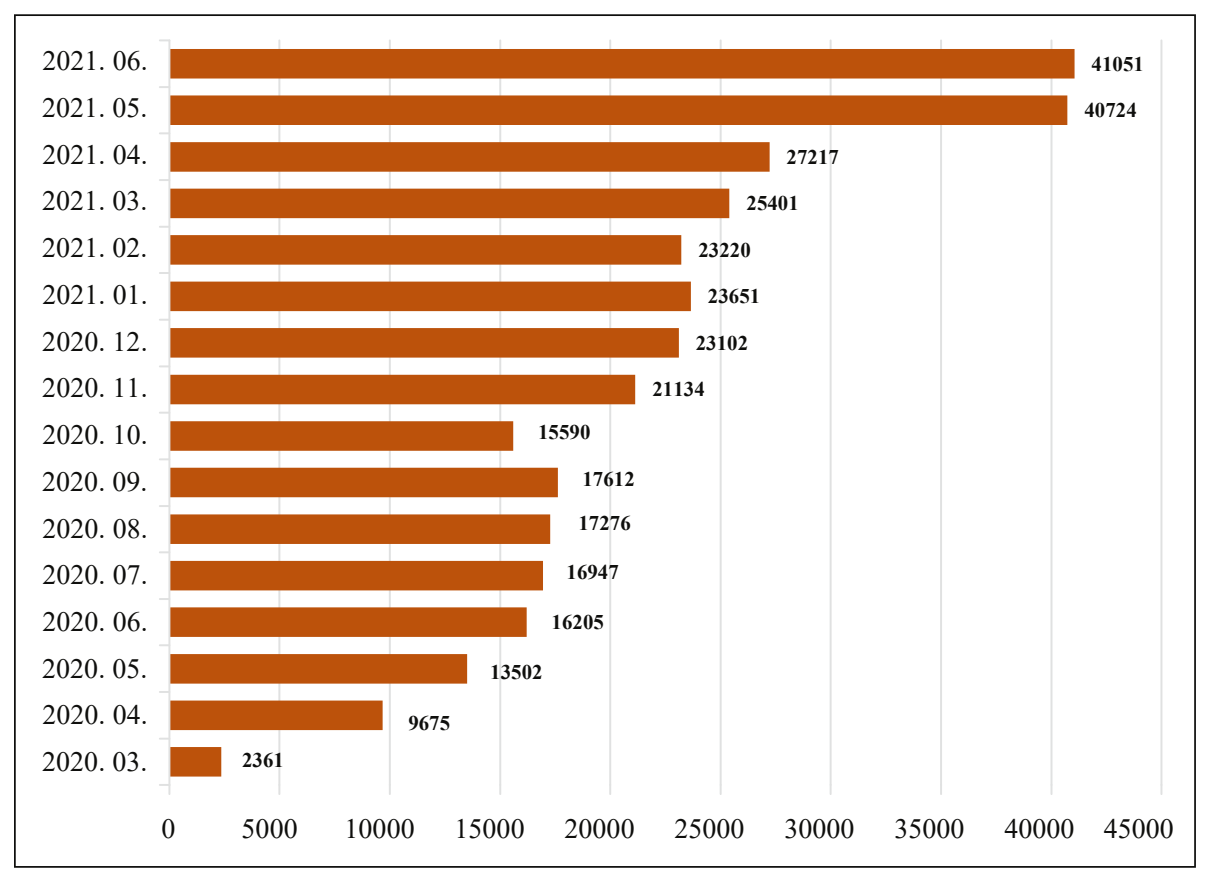

Forrás: Készítette a BVOP Fogvatartási Ügyek Szolgálata.

Azon fogvatartottak száma, akik legalább egy alkalommal éltek a Skype-hívás lehetőségével, szintén folyamatosan emelkedést mutatott. Márciusban még 1193 fö fogvatartott élt a kapcsolattartás ezen formájának lehetőségével, decemberre ez a szám 8773 főre nőtt, 2021. júniusra pedig 9368 före gyarapodott, így a felhasználók aránya 7,1\%-ról 52,45\%-ra emelkedett. A Sátoraljaújhelyi Fegyház és Börtön kiemelkedett a lehetőséggel élő fogvatartottak arányában, tekintettel arra, hogy ott 2021 márciusában már a fogvatartottak 72\%-a vette igénybe a Skype-ot. 


\section{4. számú ábra: Skype-ot használó fogvatartottak száma az összlétszámhoz képest}

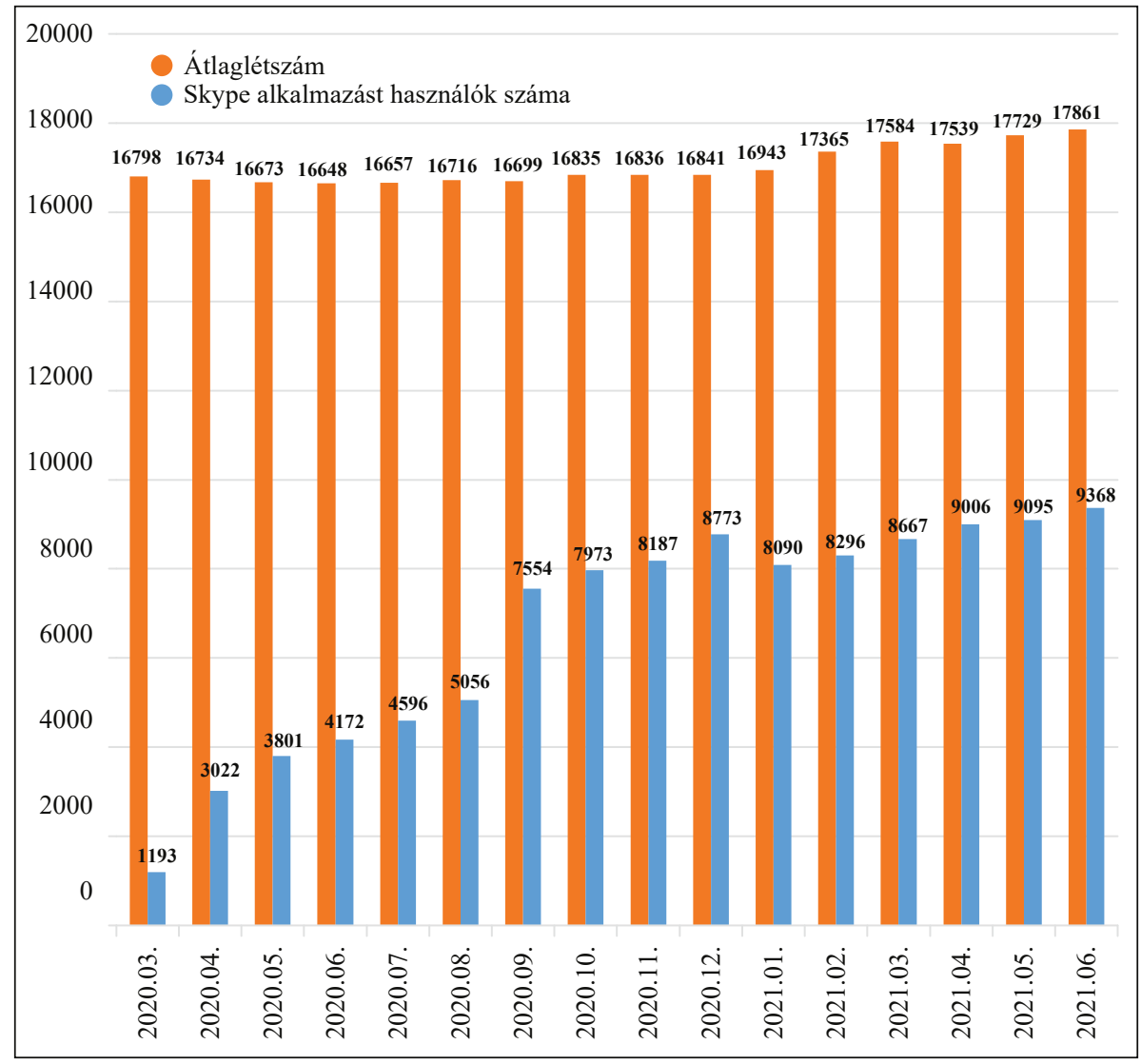

Forrás: Készítette a BVOP Fogvatartási Ügyek Szolgálata. 


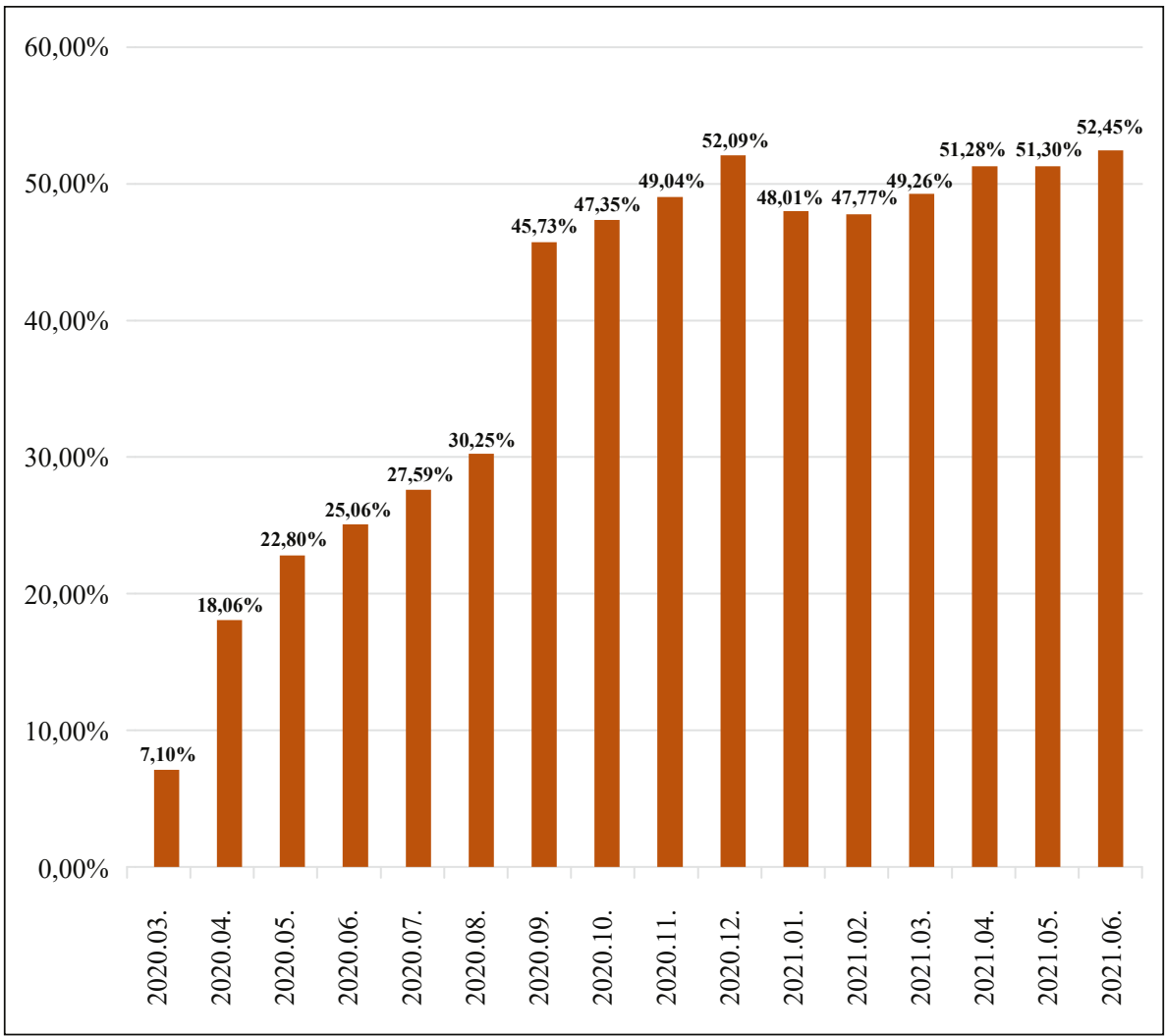

Forrás: Készítette a BVOP Fogvatartási Ügyek Szolgálata.

A felhasználók eddigi átlagos aránya 37,25\%, ami a megelőző egy év azonos időszakában látogatót fogadottak arányától is magasabb, hiszen az csupán $32,04 \%$ volt. Szeptember hónaptól kezdődően a Skype-ot használók aránya folyamatosan meghaladta az előző év megegyező időszakában látogatót fogadott fogvatartottak havi átlagos arányát is. Mindez a kapcsolattartás ezen formájának népszerüségét és a bv. intézetek végrehajtás irányába tanúsított aktív felelösségvállalását igazolja. 
6. számú ábra: A 2019 évi látogatófogadásban résztvevök

és a 2020 évi Skype lehetöséggel élök aránya (fö)

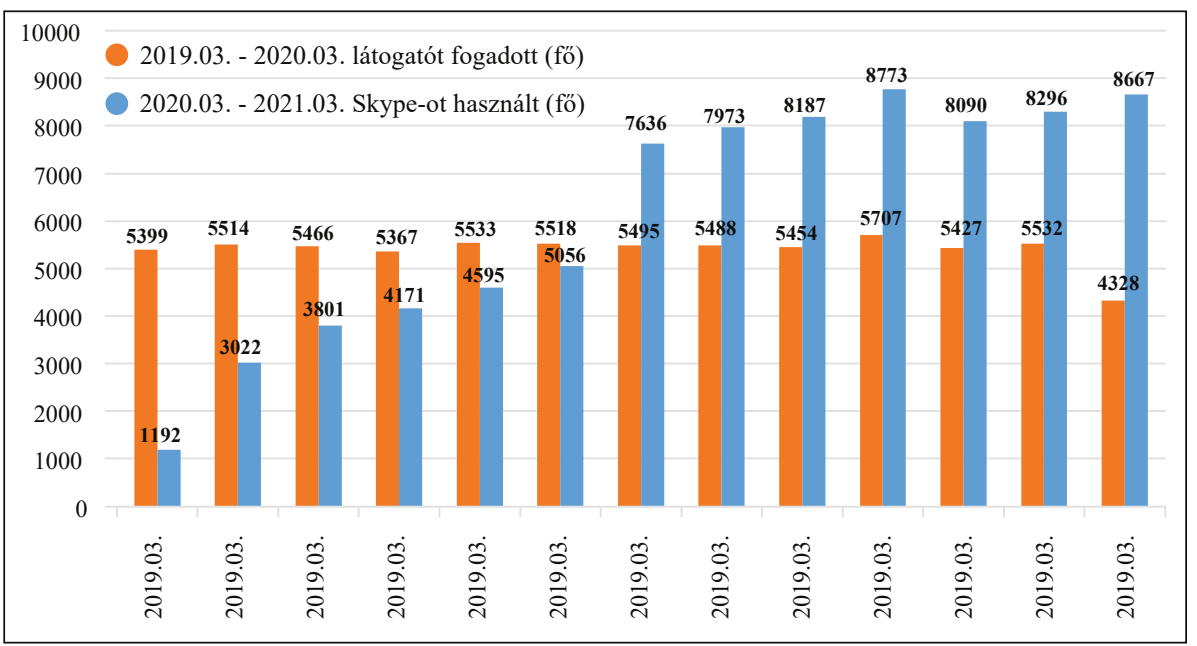

Forrás: Készítette a BVOP Fogvatartási Ügyek Szolgálata.

7. számú ábra: 2019 évi látogatófogadásban résztvevők és 2020 évi Skype lehetöséggel élők aránya (\%)

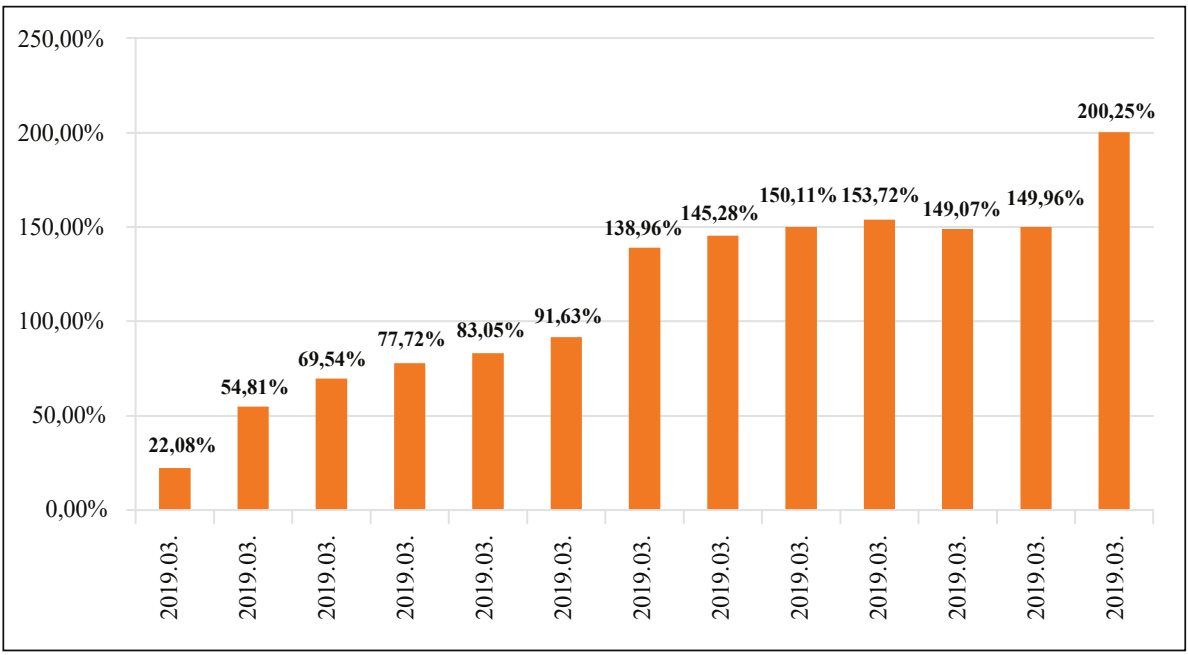

Forrás: Készítette a BVOP Fogvatartási Ügyek Szolgálata. 
A fogvatartottak kapcsolattartása alakulásának monitorozása és elemzése céljából a videóhívások tekintetében a szakterület több ízben kért adatokat és helyi tapasztalatokat bemutató információkat a bv. intézetektől. Az intézkedés bevezetése pozitív hatást gyakorolt a fogvatartottakra, föként azokra, akiket anyagi, távolsági vagy egészségügyi, életkori okok miatt egyébként nem vagy csak ritkán látogattak. Ezen felül a váratlan, rendkívüli családi események esetében soron kívül biztosítják a bv. intézetek a Skype-hívást. Ez az új kapcsolattartási forma költséghatékony a családtagokra nézve, a fogvatartottaknak pedig jóleső érzés otthoni környezetüket látni, többen megfogalmazták, hogy a videóhívásnak köszönhetően úgy érzik, mintha otthon lennének. Felmérések szerint azon fogvatartottak, akik eddig egyetlen alkalommal sem éltek a Skype-hívás lehetőségével, többségében a hozzátartozók korlátozott internet-hozzáférési lehetőségeit és alacsony technikai ismereteiket jelölték meg indokként. Az intézkedés bevezetése összességében megfelelően ellensúlyozza a látogatófogadás szünetelésének negatív hatásait, emellett a fogvatartottak hangulatára is jótékony hatással van.

Fontos megemlíteni, hogy a videóhívások végrehajtása is kockázati tényezőkkel és visszaélési lehetőségekkel járhat, mint bármely más kapcsolattartási forma - akár a látogatófogadás is. A tapasztalatok összegzése alapján - a videókapcsolat létrejöttekor, az elvárt szabályokról történő tájékoztatás ellenére - a leggyakrabban megtörtént visszaélés a kamera másik végén helyet foglaló kapcsolattartó által a fogvatartottról, videóhívásból rögzített pillanatkép vagy felvétel készítése; az engedélyezettnél több vagy nem regisztrált kapcsolattartó megjelenése a beszélgetésben; valamint konferenciabeszélgetés indítása a kapcsolattartó részéröl. Látható, hogy ezek mind a kapcsolattartók által elkövetett szabályszegések. A bv. intézetek videóhívások ellenőrzésére beosztott személyi állománya a fenti esetekben felszólítást követően a beszélgetés megszakítására intézkedett.

Szót érdemel a Skype-alkalmazáson keresztül történő kapcsolattartás tekintetében a védőkkel való kapcsolattartás is, hiszen a védőknek is lehetőséget biztosítottunk videókapcsolaton keresztül érintkezni ügyfeleikkel. A kapcsolattartói Skype-hívásokhoz képest elenyésző mennyiségben volt eddig igény az ügyvédi Skype-hívásokra, tekintettel arra, hogy a lényeges, halaszthatatlan ügyek a jóval egyszerübben kivitelezhető, fogvatartott részéről kezdeményezett telefonhívással is megoldhatók, amennyiben pedig iratok áttekintésére, aláírására volt szükség, a védők értelemszerüen a személyes látogatást választották. A hívást itt is a jelen lévő személyi állományi tag kezdeményezi, aki az ügyvédi igazolvány segítségével történő azonosítást követően a beszélgetést nem ellenőrzi tovább. 
A bv. szervek részére - azok jellegétől függően is - változó terhelést jelent a Skype-hívások lebonyolítása. Sokak szerint több adminisztratív és mozgatási feladattal járt, mint a látogatófogadás, mert több fogvatartott vette igénybe a videóhívást. Mások - jellemzően, ahol nagyobb létszámú fogvatartotti állomány van elhelyezve és alapesetben a látogatófogadások minden nap zajlanak - ennek ellenkezőjét tapasztalták, és ugyan több fogvatartottat érintett, de az adminisztráció és kísérés kevesebb személyi állományi tagot kötött le, mert bár a büntetés-végrehajtási szakterület leterheltsége nőtt, ezzel párhuzamosan a biztonsági osztályok tevékenységéből kikerülő látogatófogadásra történő előállítás és annak biztosítása miatt az ő terheik csökkentek.

Pozitív példának tekinthetők egyes bv. intézetek terheléscsökkentő intézkedései is, melyek során a látogatófogadó vagy más, nagyobb helyiséget szereltek fel több eszközzel - a megfelelö hálózat biztosításával együtt -, így egy időben több fogvatartottal tudtak videóhívást lebonyolítani, valamint a speciális részlegek is külön eszközt kaptak, hogy az ott elhelyezett fogvatartottak kísérése ne jelentkezzen plusz feladatként a személyi állomány tagjai részére. Mindezek jelentősen csökkentették a felhasznált humánerőforrás-igényeket.

A BVOP fogvatartási szakterülete folyamatosan monitorozta, és havonta elemezte a Skype-hívásokkal kapcsolatban meghatározott feladatok bv. intézetek által történő végrehajtását, melyek alapján szükséges esetben szakirányítás keretében intézkedett a hibák feltárása és megszüntetése, illetve az esetszámok és a bevont fogvatartottak számának növelése érdekében.

\section{Lehetőségek a negatív élethelyzet feldolgozására}

A humánjárvány magyarországi megjelenését követően a bv. szervezet már az országos védekezési időszak kezdetén felismerte a koronavírus bv. szervekbe történő bejutásának kockázatát, illetve az azzal járó súlyos következmények veszélyét, és a megelőzéssel összefüggő intézkedések bevezetését - egyben a személyi állomány, valamint a fogvatartottak életének és egészségének megóvását - folyamatosan prioritásként kezelte. A védekezésre történő felkészülés időszakában - melynek során monitorozva a nemzetközi gyakorlatokat, valamint a betegséggel összefüggő tendenciákat - szigorú intézkedések kerültek bevezetésre annak érdekében, hogy a vírusfertőzés veszélye a személyi állomány és a fogvatartottak körében egyaránt minimális szinten maradjon, ugyanakkor a BVOP illetékes szakterületei folyamatosan keresték a negatív élethelyzettel összefüggésben a fogvatartottakat érő káros hatások enyhítésének lehetőségét. 
A bv. intézetek reintegrációs szakterületének munkatársai központi iránymutatás mellett kiemelten kezelték a fogvatartottak egyéni és kiscsoportos foglalkozások útján történő tájékoztatását az érintkezési szabályokról, a kapcsolattartásban történt változásokról, valamint a járványügyi helyzetről, ennek során felhasználva a zárt láncú televízió rendszer, a börtönrádió, továbbá a faliújságok által nyújtott lehetőségeket is. A fogvatartottak tartós elhelyezésére szolgáló valamennyi lakózárkában televíziókészülék került biztosításra, a hiányzók pótlására a BVOP 200 db televíziókészüléket szerzett be.

A korábban leírtak szerint tehát megállapítható, hogy a fogvatartottak hangulatának figyelemmel kísérése és a bevezetett korlátozó intézkedésekre való reakcióik monitorozása a járványhelyzet során mindvégig kiemelt figyelmet kapott. Az elmúlt időszakot értékelve elmondható, hogy a koronavírus-járványnyal kapcsolatban fokozott, negatív hangulati tényező csak csekély mértékben jelentkezett. A rendelkezésre álló információk alapján nem merült fel olyan körülmény, mely a fogvatartással összefüggő, súlyos rendkívüli esemény elökészületét vetette volna fel, a fogvatartotti közösség a személyi állománnyal együttmüködő volt.

A pandémiás időszakban felülvizsgálatra került a fogvatartotti foglalkoztatás rendszere abból a szempontból, hogy mely munkaterületek esetében kell folyamatosan biztosítani a munkáltatást, és mely területeken van lehetőség a munkavégzés csökkentésére vagy átmeneti jelleggel történő beszüntetésére. A priorált munkahelyek vonatkozásában - a folyamatos munkavégzés biztosítása érdekében - meghatározásra kerültek a minimum létszámok mind a fogvatartottak, mind a foglakoztatást végrehajtó személyi állomány körében. A bv. intézetekben az ellátás szempontjából kritikus területek (mint például intézetfenntartás, élelmezés, konyha) zavartalan üzemeltetése érdekében tartalékképzésre történtek intézkedések, és a kiemelt munkahelyeken munkáltatott fogvatartottak esetében megtörtént a munkaszervezés felülvizsgálata, a fogvatartottak rotációban történő munkáltatásával pedig hatékony intézkedések történtek a folyamatos müködtetés érdekében. A COVID-19 vírus terjedését megelőző fertőtlenítési, takarítási feladatok végrehajtására az egyes bv. szervek olyan fogvatartotti munkacsoportok munkába állítására intézkedtek, melyek feladata az elöírás szerinti napi takarításon kívül a megelőző fertőtlenítés folyamatos végrehajtása volt.

A koronavírus kapcsán kialakult járványügyi helyzetre tekintettel, a 2020. március 14-én kiadott 1102/2020. (III. 14) Korm. határozat alapján 2020. március 16-ától az iskolákban a nevelés-oktatást tantermen kívüli, digitális munkarendben kellett megszervezni. A járványhelyzet hatással volt a szakmaképzések gyakorlatára, így azok - beleértve az EFOP-1.3.3-16-2016-00001 azonosítószámú, „Fogvatartottak reintegrációja” elnevezésủ kiemelt projekt (a továbbiakban: 
EFOP kiemelt projekt) keretében indult OKJ-s és iskolarendszerü felnőttképzéseket - tekintetében átmeneti leállásra volt szükség. A fogvatartotti oktatás és szakmaképzés fenntartása, valamint a fogvatartottak és a velük foglalkozó személyek (személyi állományi tagok és bejáró pedagógusok) egészségének és biztonságának megőrzése érdekében a digitális oktatás mint egyfajta új munkarend került bevezetésre a bv. szerv keretein belül.

A megváltozott eljárásrend ellenére a 2019/20-as tanév a szeptemberi beiskolázási adatokhoz képest 90\%-os eredményességi mutatóval zárult, a bv. intézetek illetékes munkatársai a tanév során kiemelt figyelmet fordítottak arra, hogy a fogvatartottak a megkezdett tanulmányaikat folytassák, és minél nagyobb arányban sikeresen teljesítsék is vizsgakötelezettségüket. A 2020/21-es tanév előkészítése során az egyik fö célkitüzés az oktatásba bevont fogvatartotti létszám szinten tartása volt, ennek érdekében az oktatás és szakmaképzés területét érintően több feladatszabás történt. A megtett intézkedéseknek köszönhetően a 2020/21-es tanév során beiskolázott fogvatartottak száma a korábbi tanévek adataihoz képest nőtt, annak ellenére, hogy a koronavírus-járvány miatt a kontaktórás tanrend helyett továbbra is távoktatás keretein belül, digitális platformon zajlottak a képzések.

A teljes egészében pandémiás időszakban eltelt 2020/2021-es tanév során a szeptemberi iskolakezdés után beiskolázottak létszámát is figyelembe véve - mindösszesen 4454 fö fogvatartott került bevonásra általános iskolai, középiskolai és felsőfokú oktatásba vagy szakmaképzésbe, akik közül 2511 fö eredményesen teljesítette az adott képzést, illetve évfolyamot, mely szám még nem végleges, mivel több szakmaképzés még nem zárult le. Említést érdemel, hogy az EFOP kiemelt projekt keretében indult, OKJ-jellegü, illetve iskolarendszerü felnőttképzések tekintetében mindösszesen 26-féle szakmaképzés indult, 1135 fő fogvatartott bevonásával.

A fentieken túl - szakmaképzésnek nem minősülö, ugyanakkor kompetenciafejlesztő - életvezetési és önismereti tréningek, német nyelvi képzések, számítástechnikai tanfolyamok, valamint ,asszertivitás elősegítése” elnevezésü foglalkozások is végrehajtásra kerültek egyes bv. intézetekben, ezzel is igazolva, hogy a járványhelyzetből adódó nehézségek ellenére a bv. szervezet kiemelt figyelmet fordított a fogvatartottak foglalkoztatásának fenntartására.

A COVID-19 járványhelyzetre tekintettel, annak fogvatartottakra gyakorolt negatív hatásainak enyhítésére a BVOP kreatív pályázatokat hirdetett a fogvatartottak számára. A programok célja a bv. intézetekben elhelyezett fogvatartottak foglalkozásba - minél nagyobb arányban - történő bevonása, ez által figyelmük és tevékenységük fokozottabb kontroll alatt tartása, önbecsülésük és felelősségérzetük fejlesztése volt. 
A „Vigyáztunk egymásra!” pályázat keretében a BVOP fogvatartási szakterülete a fogvatartottak által készített humoros vagy komoly hangvételü képzöművészeti, irodalmi alkotások, továbbá imaszövegek érkezését várta, melyek témája a koronavírussal kapcsolatos érzések, gondolatok kifejezése volt, a társadalom érzékenyítése céljából. A pályázatra több mint 600 pályamunka érkezett.

\section{4. számú kép: Nyertes munka a „,Vigyáztunk egymásra!” pályázaton}

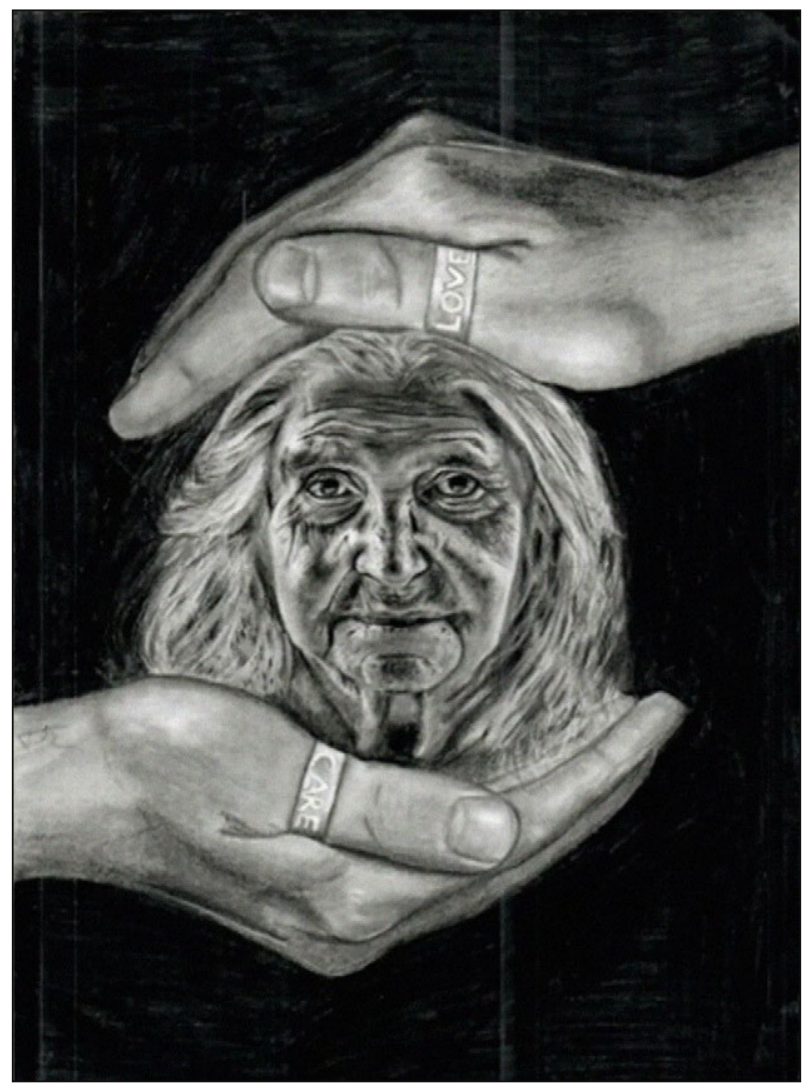

Forrás: F. R. fogvatartott különdíjas munkája a „Vigyáztunk egymásra” pályázatra.

A „Tervezz maszkot!” címen kiírt pályázat során a pályázó fogvatartottak rajzos vagy rövid írásos formában megjelenített védömaszkterveket készítettek, melyek témája szintén a koronavírussal kapcsolatos érzések, gondolatok kifejezése volt, továbbá felhívással éltek a járványügyi szabályok betartásának fontosságára. Erre a pályázatra több mint 500 pályamü érkezett. 
A Fogvatartási Ügyek Szolgálata a Kommunikációs Főosztály, valamint a Központi Kivizsgáló és Módszertani Intézet kijelölt munkatársai bevonásával bírálta el a pályamüveket, a nyertesekről valamennyi bv. intézet tájékoztatása megtörtént. Az első három helyezett mindkét pályázat esetében pénzjutalomban részesült (1. díj: $40000 \mathrm{Ft}$; 2. díj: $30000 \mathrm{Ft}$; 3. díj: $20000 \mathrm{Ft}$ ), amelyet a bv. intézetekben múködő kiétkezési boltokban vásárolhattak le, valamint a maszktervezésben helyezést elérők részére a Bv. Holding Kft. - a fogvatartottak tervei alapján -3-3 darab maszkot gyártott le, melyeket a fogvatartottak hazaküldhettek a kapcsolattartóik részére. Fontos kiemelni, hogy az elítéltek érzékenyítése, motiválása céljából a részükre készült aktuális tájékoztató kizárólag a pályaművekből került összeállításra. Ezzel párhuzamosan öt képzőművészeti alkotásból plakát készült, amelyek valamennyi bv. intézetben kihelyezésre kerültek az elítélti részlegeken, ezzel felhívva a célcsoport figyelmét arra, hogy a koronavírus-járvány első szakaszában a védekezés terén sikeresen helyt álltunk, azonban a járvány terjedésének még nincs vége.

5. számú kép: Nyertes munka a „,Tervezz maszkot!’ pályázaton

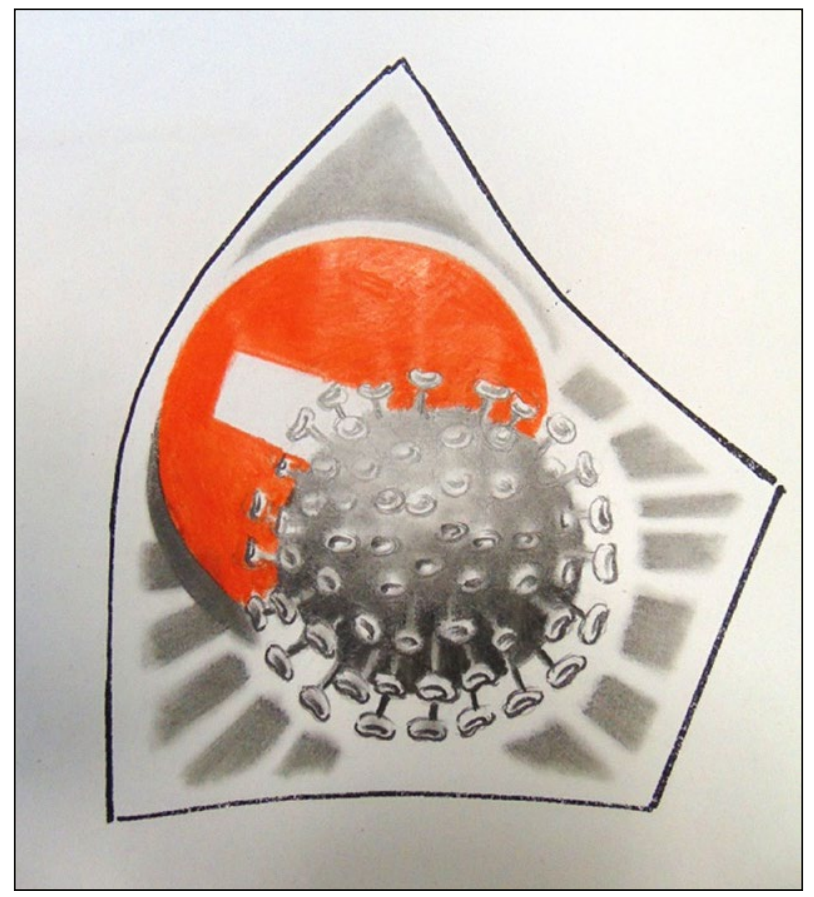

Forrás: P. A. fogvatartott különdíjas munkája a „Tervezz maszkot!” c. pályázatra. 
Az intézeti pszichológusok kellő figyelmet fordítottak a személyi állomány és a fogvatartottak körében kialakuló krízishelyzetek megelőzésére és kezelésére, a szükséges terápiás beavatkozások biztosításával. A járványhelyzet ellenére nemcsak a pszichológusok, de a lelkészek által felkínált gondozás is folyamatosan elérhető volt a fogvatartottak számára. Értelemszerüen mindkét szolgáltatás során kerültük a nagyobb csoportok bevonásával járó programokat, azonban a kiscsoportos és egyéni foglalkozások rendszeresek voltak, és a fogvatartottak egyéni meghallgatása, ellátása kérelemre is biztosított volt. Az ellátások, egyéni foglalkozások a kérelmek ügyintézési határidején belül (30 nap), a lehető legrövidebb idő elteltével megtörténtek, míg a sürgősségi ellátást igénylő esetekben a szolgáltatások soron kívül lettek biztosítva. A lelki gondozások kapcsán említésre méltó, hogy azok dvd- és hangfelvételek, valamint írásos anyagok felhasználásával kerültek végrehajtásra.

\section{Összegzés}

A koronavírus-járvány által átszabott büntetés-végrehajtás ebben a váratlan helyzetben is igyekezett a fogvatartás biztonságának megtartása mellett, az egészség és a közösség védelmét elötérbe helyezve helytállni. Az elítéltek és hozzátartozóik folyamatos érzékenyítése és tájékoztatása - a fokozatosan szigorodó rendelkezések és intézkedések bevezetéséről - hatékonyan elősegítette a megváltozott körülmények elfogadását, ezáltal a koronavírus-járvány okozta stresszfaktor is csökkenthető volt. Mint ahogyan az látható volt, a Skype-hívások lehetőségével a fogvatartottak - saját és kapcsolattartóik igényeinek megfelelően - aktívan éltek. Az intézkedések bevezetése összességében megfelelően ellensúlyozta a látogatófogadás szünetelésének negatív hatásait, és 2021. június 30-án - a kézirat lezárásának napján - kijelenthető, hogy az eltelt időszakot a fogvatartottak együttmüködésével a bv. szervezet sikeresen átvészelte, és a bevezetett védelmi intézkedések, valamint az önkéntesen jelentkező személyek - a fogvatartotti populáció közel $80 \%$-a - védőoltásban részesítésének eredményeként 2021. július 1-jei hatállyal - meghatározott feltételek teljesülése mellett - ismételten lehetőség nyílik a személyes találkozáson alapuló látogatófogadásra.

A pandémiás időszakban a bv. szervezetre háruló többletterhek ellenére is eredményes szakmai munka folyt a hazai bv. intézetekben, és visszatekintve a mögöttünk álló hónapokra megállapítható, hogy a közrendet és a köznyugalmat megzavaró, súlyos rendkívüli esemény nem következett be. Ebben természetesen szerepet játszott a személyi állomány jogszerü és szakszerủ szolgálatellátása, 
a bevezetett intézkedések hatékony végrehajtása, de szükség volt arra is, hogy átérezve a személyes felelősségvállalásuk hangsúlyos szerepét, a fogvatartottak részéről is együttmüködés volt tapasztalható.

A hozzátartozók korlátozott internet-hozzáférési lehetőségeinek és alacsony technikai ismereteinek kiküszöbölése érdekében kapcsolatfelvétel valósult meg a Digitális Jólét Program képviselőivel, hogy az általuk müködtetett Digitális Jólét Pontokon, közösségi internethasználat segítségével az érintett hozzátartozók és fogvatartottak között is létrejöhessen a Skype-kapcsolat. Itt biztosított az ingyenes internet-hozzáférés, emellett a jelen lévő mentorok az alkalmazás használatát is segítenek elsajátítani a hozzájuk fordulóknak. Ez a projekt jelenleg még szünetel, tekintettel arra, hogy a program keretében létesített pontok főként könyvtárakban üzemelnek, melyek a járványhelyzet miatt egyelöre még zárva tartanak. A pozitív tapasztalatokra tekintettel, a BVOP kezdeményezte az elektronikus kapcsolattartási forma bevezetését a büntetések, az intézkedések, egyes kényszerintézkedések és a szabálysértési elzárás végrehajtásáról szóló 2013. évi CCXL. törvénybe és annak végrehajtási rendeletébe, amely elfogadásra került és 2021. január 1-jétől hatályba lépett, így már jogszabály által is biztosított a fogvatartottak elektronikus kapcsolattartási lehetősége.

\section{A cikkben található online hivatkozások}

URL1: Megelözö intézkedések a koronavírus-járvány miatt a hazai börtönökben. https://bv.gov. $\mathrm{hu} / \mathrm{hu} / \mathrm{node} / 3592$

URL2: Járványügyi tájékoztatási call centerek a börtönökben. https://bv.gov.hu/hu/node/3592 URL3: Skype útmutatót készitett a büntetés-végrehajtás a fogvatartottak hozzátartozóinak. https:// bv.gov.hu/hu/intezetek/bvszervezet/hirek/3619

\section{Alkalmazott jogszabályok}

16/2014. (XII. 19.) IM rendelet a szabadságvesztés, az elzárás, az előzetes letartóztatás és a rendbírság helyébe lépő elzárás végrehajtásának részletes szabályairól

2013. évi CCXL. törvény a büntetések, az intézkedések, egyes kényszerintézkedések és a szabálysértési elzárás végrehajtásáról

2020. évi LVIII. törvény a veszélyhelyzet megszűnésével összefüggő átmeneti szabályokról és a járványügyi készültségről

37/2020 (VII.24.) OP utasítás a videóhívással megvalósuló elektronikus kapcsolattartás eljárásrendjéről 
40/2020. (III. 11.) Korm. rendelet a veszélyhelyzet kihirdetéséről

71/2020. (III.27.) Korm. rendelet a kijárási korlátozásról

90/2020. (IV. 5.) Korm. rendelet a veszélyhelyzet kihirdetésével összefüggésben egyes büntetés-végrehajtási szabályok módosításáról

\section{A cikk APA szabály szerinti hivatkozása}

Kovács M. (2021). A koronavírus-járványhelyzet során kialakított fogvatartási stratégiák bemutatása, a védekezéssel és megelőzéssel kapcsolatosan végrehajtott feladatok és jó gyakorlatok tükrében. Belügyi Szemle, 69(SI5), 65-90. https://doi.org/10.38146/BSZ.SPEC.2021.5.3 